\title{
OBSERVATION ON VOID FORMED IN OXIDE SCALE OF Fe-Cr-Ni ALLOY AT 1073K IN DRY AND HUMID ENVIRONMENTS
}

\author{
AKbar Kaderi ${ }^{1}$, AhMad Zaki Mohd Zainal ${ }^{1}$, HaNAfi ANI ${ }^{1}$ \\ AND RAIHAN OTHMAN ${ }^{2}$ \\ ${ }^{I}$ Department of Manufacturing and Materials Engineering, \\ ${ }^{2}$ Department of Science in Engineering, \\ Kulliyyah of Engineering, International Islamic University Malaysia, \\ Jalan Gombak, 53100, Kuala Lumpur, Malaysia. \\ mhanafi@iium.edu.my
}

\begin{abstract}
Void formation in oxide scale during high temperature oxidation is a common phenomenon. Over a long period of time voids will affect the mechanical property of scales by influencing the cracking and spalling. Voids formed in dry environment are different than that of formed in humid environment. With the presence of water vapor in humid environment the formation of void will increase, thus greater number of void compared to that in dry environment. Fe-Cr-Ni alloy samples were exposed isothermally at $1073 \mathrm{~K}$ in air $\left(P_{\mathrm{O}_{2}}=0.21 \mathrm{~atm}=2.1 \times 10^{5} \mathrm{~Pa}\right)$ and humid (air + steam) environments. XRD analysis done to all samples confirms that $\mathrm{Fe}_{2} \mathrm{O}_{3}, \mathrm{Fe}_{3} \mathrm{O}_{4}$, $\mathrm{NiCr}_{2} \mathrm{O}_{4}, \mathrm{FeCr}_{2} \mathrm{O}_{4}, \mathrm{Cr}_{2} \mathrm{O}_{3}$ and $\mathrm{NiO}$ phases exist in the scale. EDX analysis done shows varying compositions of $\mathrm{Fe}, \mathrm{Cr}, \mathrm{Ni}$ and $\mathrm{O}$ in outer and inner oxide scale, oxide scale/metal interface and metal. Field emission scanning electron microscope (FE-SEM) was used to investigate voids formed in the cross sections of the oxidized samples. Volume fraction of voids in the oxide scale was calculated in accordance to the cross sectional area fraction of voids in the scale. It shows that $\mathrm{Fe}-\mathrm{Cr}-\mathrm{Ni}$ alloy samples exposed in humid environment has as high as $71 \%$ more voids than that exposed in dry environment. It is concluded that the humid environment increased the number of void formed in the oxide scale, thus facilitates the exfoliation of protective scale during the high temperature oxidation.
\end{abstract}

ABSTRAK: Pembentukan gelembung udara di dalam lapisan oksida ketika proses pengoksidaan di suhu tinggi merupakan satu fenomena biasa. Pada satu jangka masa yang panjang gelembung-gelembung ini akan memberi kesan kepada sifat mekanikal oksida dengan mempengaruhi pembentukan keretakan dan pengelupasan oksida. Gelembung udara yang terbentuk di dalam persekitaran kering berbeza daripada yang terbentuk di dalam persekitaran lembap. Dengan adanya wap air, pembentukan gelembung akan bertambah berbanding yang terbentuk di dalam persekitaran kering. Sampel aloi Fe-Cr-Ni telah dioksidakan secara isoterma pada suhu $1073 \mathrm{~K}$ di dalam udara $\left(P_{\mathrm{O}_{2}}=0.21 \mathrm{~atm}=2.1 \times 10^{5} \mathrm{~Pa}\right)$ dan lembap (udara + wap air). Analisis Pembelauan Sinar - X (XRD) kepada semua sampel menunjukkan oksida yang terbentuk ialah $\mathrm{Fe}_{2} \mathrm{O}_{3}, \mathrm{Fe}_{3} \mathrm{O}_{4}, \mathrm{NiCr}_{2} \mathrm{O}_{4}, \mathrm{FeCr}_{2} \mathrm{O}_{4}, \mathrm{Cr}_{2} \mathrm{O}_{3}$ dan NiO. Analisis Penyebaran Tenaga Sinar - X (EDX) menunjukkan komposisi $\mathrm{Fe}, \mathrm{Cr}$, Ni dan $\mathrm{O}$ yang berubah - ubah di lapisan oksida luar dan dalam, oksida/ antara muka logam dan logam. Mikroskop Imbasan Elektron-Pancaran Medan (FE-SEM) digunakan untuk meneliti gelembung di dalam oksida pada keratan rentas sampel. Pecahan isi padu gelembung yang terbentuk pada oksida dikira dengan merujuk kepada pecahan luas keratan rentas pada oksida tersebut. Sampel aloi Fe-Cr-Ni yang dioksidakan di dalam persekitaran lembap 
mempunyai kandungan gelembung udara $71 \%$ lebih banyak berbanding dengan yang dioksidakan di dalam persekitaran kering. Kesimpulannya persekitaran lembap meningkatkan bilangan gelembung yang terbentuk di dalam lapisan oksida, sekaligus memudahkan pengelupasan oksida semasa pengoksidaan suhu tinggi.

KEYWORDS: high temperature oxidatio;, $\mathrm{Fe}-\mathrm{Cr}$-Ni alloy; void formation; quantitative analysis of voi; dry environment; humid environment

\section{INTRODUCTION}

Formation of voids in oxide scale especially in the proximity of metal/oxide interface or outer oxide scale/inner oxide scale interface is common in metals during high temperature oxidation. The formation will affect the oxidation mechanism and mechanical properties of the scale and also the metal itself. The tendency of voids to concentrate at outer oxide scale/inner oxide scale interface will result in spalling of the outer oxide scale [1].

Voids within iron oxide scales and the iron-rich oxides formed on dilute $\mathrm{Fe}-\mathrm{Cr}$ and $\mathrm{Fe}-\mathrm{Al}$ alloys developed far more faster in the presence of water vapor. Rahmel et al. [2,3] have reported that presence of $\mathrm{H}_{2} \mathrm{O}(\mathrm{g})$ caused the scale to develop porosity. Ehlers et. al. [4] observed that 9 mass\% $\mathrm{Cr}$ ferritic steels form rapidly growing scales of porous magnetite plus spinel during oxidation at $923 \mathrm{~K}$ in gases containing water vapor.

Contemporary literatures [2-6] on effect of water vapor on $\mathrm{Fe}-\mathrm{Cr}$ or $\mathrm{Fe}-\mathrm{Al}$ alloys mostly describe formation of voids in qualitative manner but few are attempting to study it quantitatively. Understanding on the formation of voids quantitatively is very important because voids formation affect development of scales microsructure. Maruyama et al. [7] proposed that void formation in a growing oxide scale during high temperature oxidation of a metal closely related with the divergence of ionic fluxes. Further improvement of the treatment by Ueda et. al. [8], by including all ionic fluxes into the calculation of the chemical potential distribution and quantitatively explained the position and the volume of voids formed in the magnetite scale. Until recently, Maruyama et al. [9] has successfully applied the quantitative estimation on the void formed in a single phase magnetite scale grown on iron substrate at $823 \mathrm{~K}$ in oxdizing environment containing oxygen partial pressure, $P_{\mathrm{O}_{2}}=4.2 \times 10^{-13} \mathrm{~Pa}$. However, most qualitative and quantitative studies on void formation cited earlier done in a strictly controlled oxidizing environment especially by lowering the $P_{\mathrm{O}_{2}}$, so that only specific oxide scale grows on the metal substrate at specific temperature.

Therefore in this study, quantitative observation was focusing on void formed in a multiple oxide scale grown on Fe-Cr-Ni alloy at $1073 \mathrm{~K}$ in normal air $\left(P_{\mathrm{O}_{2}}=0.21 \mathrm{~atm}=\right.$ $2.1 \times 10^{5} \mathrm{~Pa}$ ) and humid (air + steam) environment.

\section{EXPERIMENTAL METHODS}

\subsection{Sample Preparation of Fe-Cr-Ni Alloys}

$\mathrm{Fe}-\mathrm{Cr}-\mathrm{Ni}$ alloys were prepared from high-purity $\mathrm{Fe}(99.99 \%), \mathrm{Cr}$ (99.99\%), Ni (99.99\%) plates by arc melting in Ar gas. The alloys were further annealed for $86.4 \mathrm{ks}$ at $1373 \mathrm{~K}$ in vacuum. After annealing the alloys were sliced into coupons of $1 \mathrm{~mm}$ thick and the surfaces of the coupons were ground with emery paper up to \#2000. Then the samples were polished with $3 \mu \mathrm{m}$ alumina paste to a mirror-like finish. The samples were cleaned 
with acetone via ultrasonic agitation. The chemical composition of the alloys were analyzed through Energy Dispersive X-Ray (EDX). The chemical composition of Fe-Cr$\mathrm{Ni}$ alloys are shown in Table 1.

Table 1: Chemical composition of Fe-10 mass \% Cr-10 mass \% Ni alloy.

\begin{tabular}{cccc}
\hline Element & $\mathrm{Fe}$ & $\mathrm{Cr}$ & $\mathrm{Ni}$ \\
\hline Mass \% & $\mathbf{7 9 . 6 1}$ & $\mathbf{1 0 . 7 8}$ & $\mathbf{9 . 6 1}$ \\
\hline
\end{tabular}

\subsection{Oxidation Experiment of Fe-Cr-Ni Alloys}

Figure 1 shows the experimental setup. The sample was placed at the isothermal zone of the furnace. An R-type thermocouple was placed at the isothermal zone beside the sample to monitor the temperature. The distance between the sample and the thermocouple is $5 \mathrm{~mm}$. The isothermal zone is $30 \mathrm{~mm}$ in range.

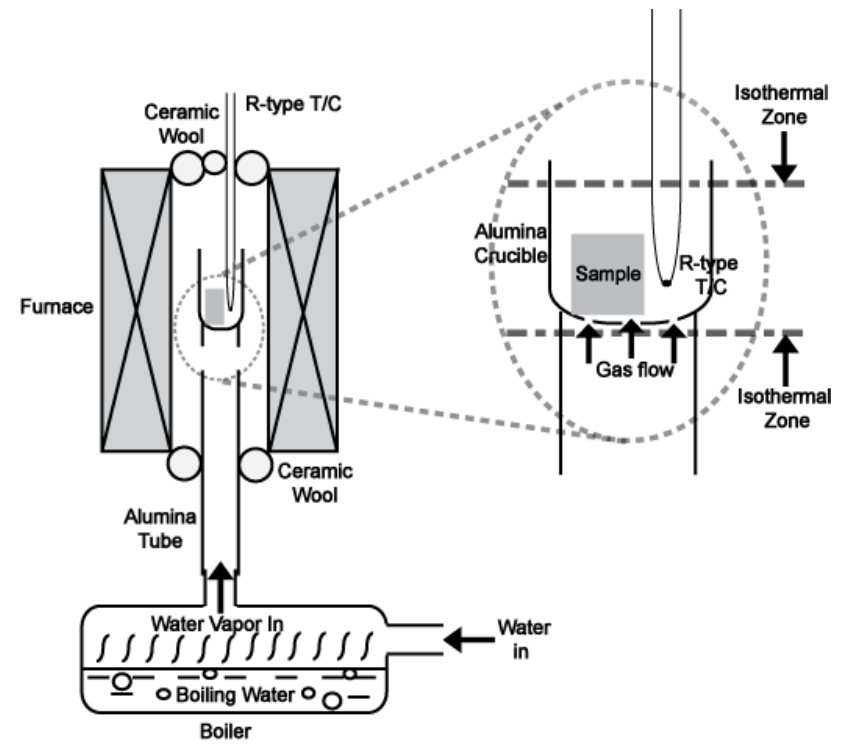

Fig. 1: Experımental setup ıor oxıaation in numia conaıtıon at $1073 \mathrm{~K}$.

For the oxidation in dry environment, the sample was heated to $1073 \mathrm{~K}$ and held for $86.4 \mathrm{ks}$ and $172.8 \mathrm{ks}$ respectively in air. For the oxidation in humid environment, a boiler is placed directly below the furnace. The water vapor was channeled into the furnace once the heating process started. The continous supply of water to the boiler will ensure that the water vapor will be produced continously throughout the oxidation process. The oxidation process in humid environment was also hold for $86.4 \mathrm{ks}$ and $172.8 \mathrm{ks}$ respectivey. After oxidation, the samples are cooled to room temperature in the furnace.

\subsection{Phase Identification}

Oxide phases formed were analyzed by X-ray diffraction (XRD) using the divergence slit of 1 degree. The diffraction angle is from $20^{\circ}$ to $80^{\circ}$ and the scanning speed was $3.0000 \% \mathrm{~min}$.

The XRD patterns were compared with $\alpha$-Fe (JCPDS 00-006-0696), FeO (JCPDS 00006-0615), $\mathrm{Fe}_{2} \mathrm{O}_{3}$ (JCPDS 01-085-0599), $\mathrm{Fe}_{3} \mathrm{O}_{4}$ (JCPDS 00-019-0629), $\mathrm{NiFe}_{2} \mathrm{O}_{4}$ (JCPDS 
01-074-1913), $\mathrm{NiCr}_{2} \mathrm{O}_{4}$ (00-023-0432), $\mathrm{FeCr}_{2} \mathrm{O}_{4}$ (JCPDS 00-034-0140), $\mathrm{Cr}_{2} \mathrm{O}_{3}$ (00-0381479), and NiO (JCPDS 00-047-1049).

\subsection{Chemical Composition of Each of Main Elements after Oxidation: Outer Oxide Scale, Inner Oxide Scale, Inner Oxide Scale/Fe-Cr-Ni Alloy Interface and Fe-Cr-Ni Alloy}

The concentration of main elements of each samples after being oxidized were quantitatively determined by EDX. The analysis was done on 4 spots; Spot 1: Outer oxide scale, Spot 2: Inner oxide scale, Spot 3: Metal/Oxide interface and Spot 4: Metal. Figure 2 shows an example of an area of a sample's 4 spots being analyzed to determine the main elements concentration.

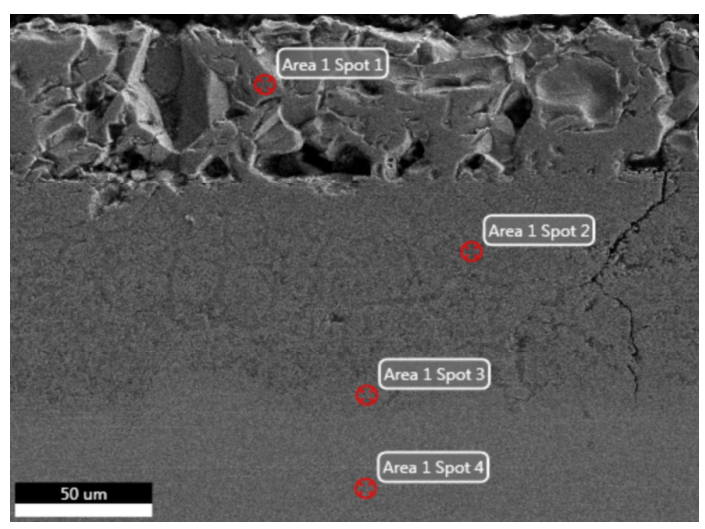

Fig. 2: An FE-SEM micrograph shows the spots for EDX analysis.

\subsection{Volume Fraction of Voids in the Oxide Scale}

Oxidized samples were mounted individually in resin. Prior to mounting, $2 \mathrm{~mm}$ of each of sample was cross - sectioned by diamond saw. Figure 3 is a schematic of the samples after being cross-sectioned. The exposed cross - section part of the samples was ground up to \#2000. Then the samples were polished with $0.05 \mu \mathrm{m}$ alumina to a mirrorlike finish.

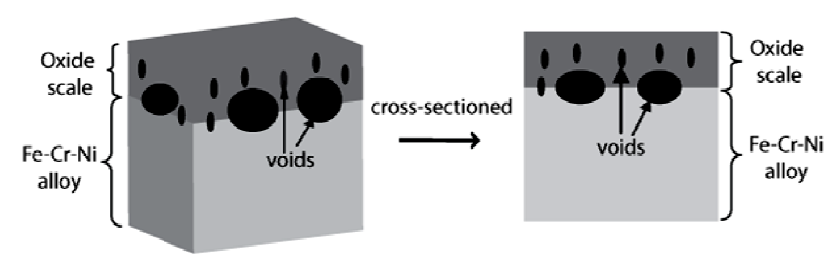

Fig. 3: Schematics of samples after being cross-sectioned.

Surface morphology was observed by field emission scanning electron microscopy (FESEM). Grids of uniformed size were traced on each images and area fraction of voids in the scale was measured. It was assumed that the volume fraction of void in the scale equal to the cross-sectional area fraction of voids in the scale [10]. The same assumption was applied by Akiba et al. [11], in order to calculate voids formed in $\mathrm{NiO}$ grown of $\mathrm{Ni}$ substrate at $1373 \mathrm{~K}$. 


\section{RESULTS AND DISCUSSION}

\subsection{Phase Identification by XRD and EDX Analysis}

Figure 4 shows the XRD patterns of the sample surfaces.It was shown there is formation of $\mathrm{Fe}_{2} \mathrm{O}_{3}$ in all samples. Less intense and small peaks of $\mathrm{Cr}_{2} \mathrm{O}_{3}$ and $\mathrm{NiO}$ phase only detected for samples oxidized in dry environment. The formation of $\mathrm{FeCr}_{2} \mathrm{O}_{4}$ and $\mathrm{NiCr}_{2} \mathrm{O}_{4}$ spinels were observed in all samples. $\mathrm{Fe}_{3} \mathrm{O}_{4}$ were also detected only in samples oxidized both in humid and dry environment.

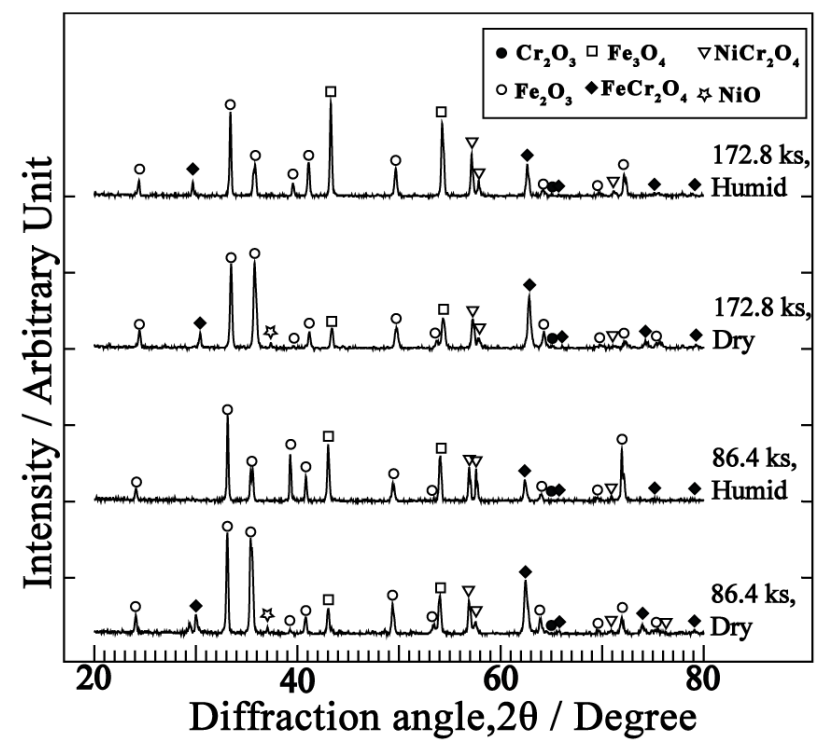

Fig. 4: XRD patterns of samples in dry and humid environment at $1073 \mathrm{~K}$ after $86.4 \mathrm{ks}$ and $172.8 \mathrm{ks}$.

The EDX Profile was examined as shown in Fig. 5a, b, c, and d. The metal/oxide scale interface for all samples were set at $\mathrm{x}=0 \mu \mathrm{m}$ for the sake of easy observation. The elemental composition of $\mathrm{Fe}$ in the outer scale is within a range of $67 \%-72 \%$. The composition of $\mathrm{O}$ in the outer oxide scale is also substantial for all samples which are showing a range of $30-35 \%$. Correspond with the XRD pattern, the predomination of $\mathrm{Fe}$ and $\mathrm{O}$ concentration in the outer scale can be explained by the presence of $\mathrm{Fe}_{2} \mathrm{O}_{3}$ and $\mathrm{Fe}_{3} \mathrm{O}_{4}$. The inner scale shows the element of $\mathrm{Fe}$ as well as $\mathrm{O}$ has decreased. There are traces of $\mathrm{Ni}$ and $\mathrm{Cr}$ concentration in this inner scale compared to the outer scale. The inner scale is corresponding to the XRD pattern of $\mathrm{NiCr}_{2} \mathrm{O}_{4}$ and $\mathrm{FeCr}_{2} \mathrm{O}_{4}$. In the internal oxide zone (IOZ), it was observed that the concentration of Fe increased while the concentration of $\mathrm{O}$ is decreasing. The concentration of $\mathrm{Cr}$ and $\mathrm{Ni}$ also shows increment compared to that of in the inner scale zone. These suggested that spinel oxides of $\mathrm{NiCr}_{2} \mathrm{O}_{4}$ and $\mathrm{FeCr}_{2} \mathrm{O}_{4}$ formed in IOZ region. Finally, in the $\mathrm{Fe}-\mathrm{Cr}-\mathrm{Ni}$ alloy region the concentrations of $\mathrm{Fe}, \mathrm{Cr}$, and $\mathrm{Ni}$ are at their highest but the concentration of $\mathrm{O}$ is zero. The decreasing oxygen composition closer to the alloy and decreasing metal composition further away from the alloy was caused by the diffusion of metal ion and oxide ion under the influence of chemical potential gradients. 

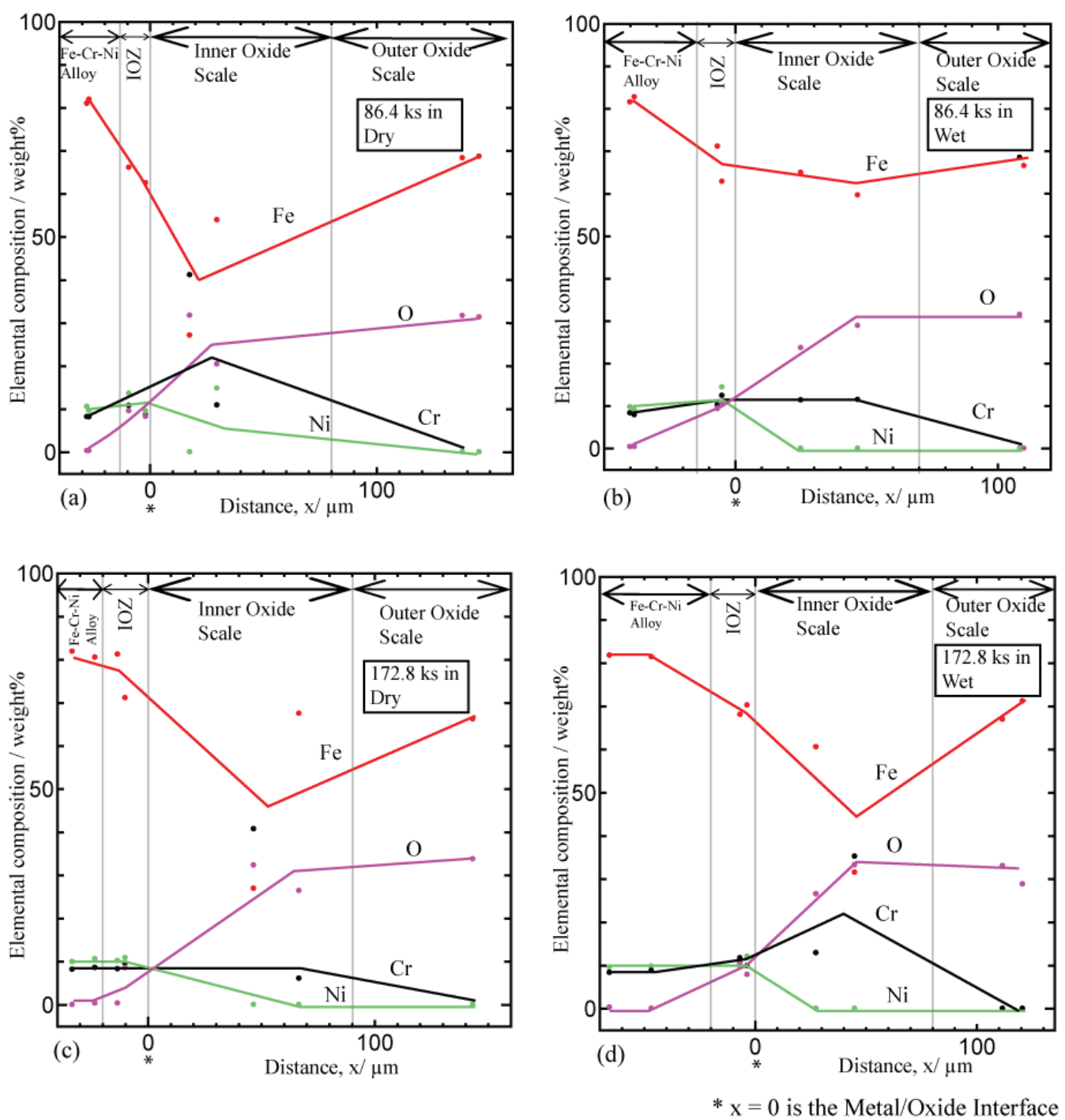

Fig. 5: EDX profile of samples in dry and humid environment at $1073 \mathrm{~K}$ after $86.4 \mathrm{ks}(\mathrm{a}, \mathrm{b})$ and $172.8 \mathrm{ks}(\mathrm{c}, \mathrm{d})$.

\subsection{Volume Fraction of Voids in the Oxide Scale}

Figure 6 shows the FE-SEM micrographs of cross section of samples oxidized in dry and humid environment. Voids are observed to be different from the inner oxide scale than that of outer oxide scale for all samples.

Larger size of voids are observed in the vicinity of outer oxide scale /inner oxide scale. Smaller size of voids are observed to be congregated in the metal reservoir of inner oxide scale. For samples oxidized in dry environment, voids are spherical in shape. While samples oxidized in wet environment, voids are columnar in shape. 

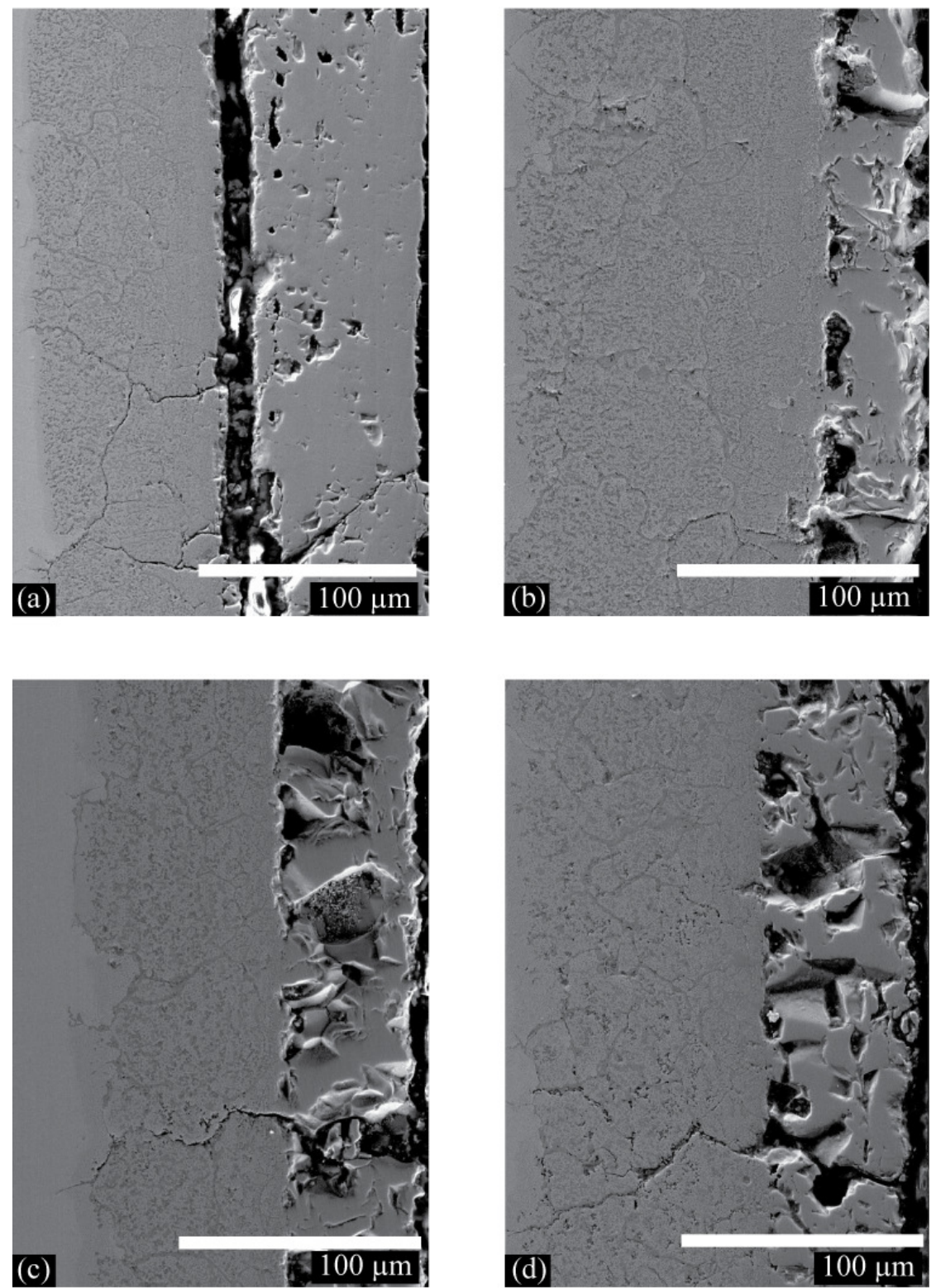

Fig. 6: FE-SEM micrographs of cross section of samples oxidized in dry $(a, b)$ and humid (c, d) environment at $1073 \mathrm{~K}$ after $86.4 \mathrm{ks}$ (a, c) and $172.8 \mathrm{ks} \mathrm{(b,} \mathrm{d).}$

Figure 7 shows the volume fraction of voids in the inner oxide scale. The volume fraction of voids is in good agreement with the governing equation (1) proposed by Maruyama [9]:

The volume fraction of voids in scales, $f_{V}$ :

$$
f_{V}=\frac{V_{\mathrm{void}}^{\mathrm{ox}}}{(L-l) \times 1 \times 1}
$$

$f_{V}$ is volume fraction of voids in scale, $V_{\text {void }}^{\text {ox }}$ is void formation in the scale during oxidation, $l$ is inner scale and $L$ is outer scale. Multiplication of the length, $(L-l)$ with $1 \times$ 1 is to project the void formed into cubic dimension represented in a real oxide scale formed on the Fe-Cr-Ni alloy. Equation (1) shows the formation of voids is independent of time. 


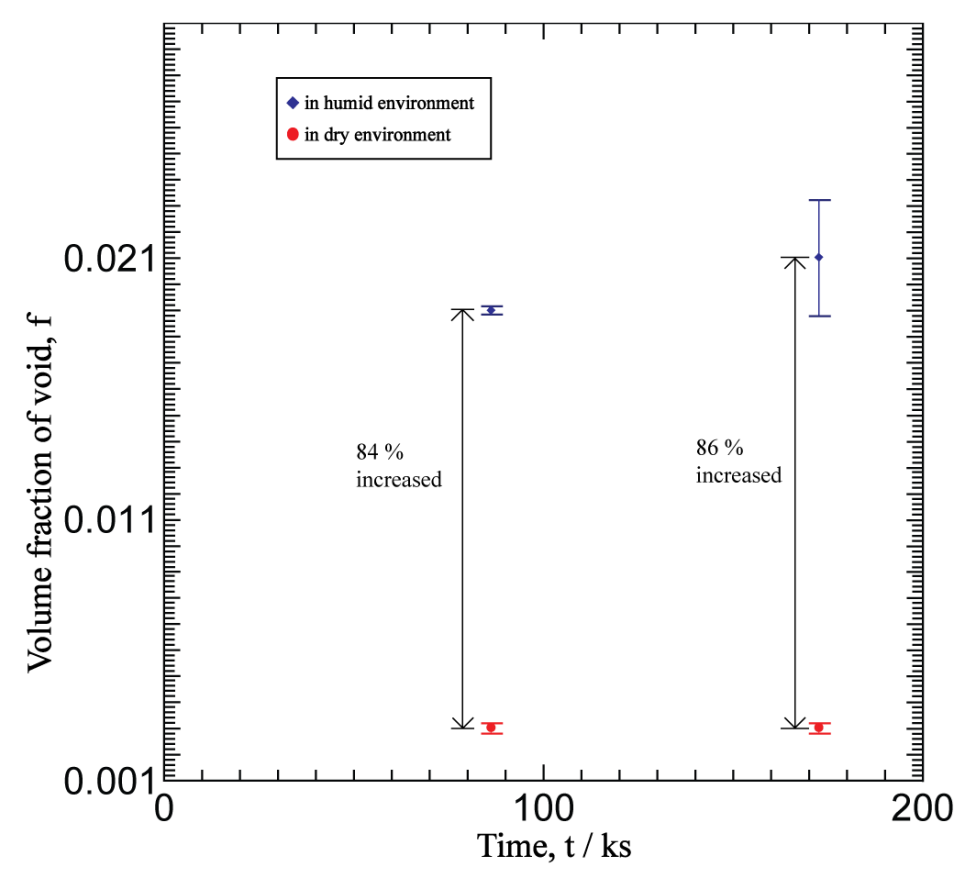

Fig. 7: The area fraction of voids in the inner oxide scale measured in the cross section of samples oxidized in dry and humid environment at $1073 \mathrm{~K}$ after $86.4 \mathrm{ks}$ and $172.8 \mathrm{ks}$.

Figure 8 shows the volume fraction of voids in the outer oxide scale. However an anomaly occurred for volume fraction of voids in outer oxide scale of samples oxidized in dry environment. It was shown that the volume fraction of voids in outer scale increased with time.

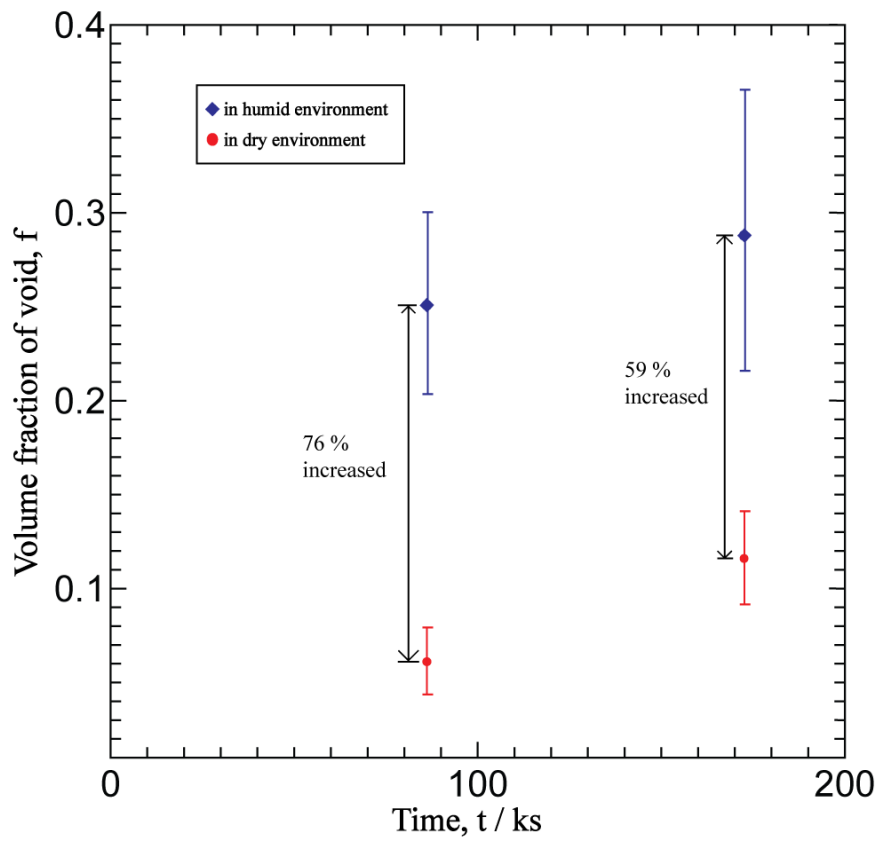

Fig. 8: The area fraction of voids in the outer oxide scale measured in the cross section of the sample oxidized in dry and humid environment at $1073 \mathrm{~K}$ after $86.4 \mathrm{ks}$ and $172.8 \mathrm{ks}$. 
Nevertheless, the increases in volume fraction of voids for samples oxidized in humid environment shown in Fig. 7 and 8 are phenomenal than that of samples oxidized in dry environment. The increase is ranging from $59 \%$ to $86 \%$.

It is interesting to note that the volume fraction of voids in outer oxide scale in this study are in a range of 0.06 to 0.29 . Studies on void formation in magnetite scale by Maruyama [9] shows very small volume fraction of voids in a range of 0.05 to 0.06 . Meanwhile, $\mathrm{NiO}$ scale on Ni by Akiba [11] shows volume fraction of voids less than 0.01 . Both studies were conducted in a controlled $P_{\mathrm{O}_{2}}$ environment. Therefore, the fact that the oxidation for the current study was done in normal air with higher $P_{\mathrm{O}_{2}}$ has contributed to the formation of greater magnitude of void in the outer scale.

\section{CONCLUSION}

The void formation in oxide scales of $\mathrm{Fe}-\mathrm{Cr}-\mathrm{Ni}$ alloy samples exposed isothermally at $1073 \mathrm{~K}$ in air $\left(P_{\mathrm{O}_{2}}=0.21 \mathrm{~atm}=2.1 \times 10^{5} \mathrm{~Pa}\right)$ and humid (air + steam $)$ were investigated. It has been shown that the protective $\mathrm{Cr}_{2} \mathrm{O}_{3}$ phases and $\mathrm{NiO}$ phases occurred in samples oxidized in dry environment while non-protective $\mathrm{Fe}_{3} \mathrm{O}_{4}$ phase occurred in all samples oxidized in dry and humid environment. The volume fraction of voids formed in inner scale increased by $84 \%$ for $86.4 \mathrm{ks}$ and $86 \%$ for $172.8 \mathrm{ks}$ when oxidized in humid environment. On the other hand, volume fraction of voids formed in outer scales increased by $76 \%$ for $86.4 \mathrm{ks}$ and $59 \%$ for $172.8 \mathrm{ks}$ when oxidized in humid environment. The oxygen partial pressure, $P_{\mathrm{O}_{2}}$ greatly influenced the volume fraction of voids formed in the oxide scale of Fe-Cr-Ni alloy. Hence the oxidation in air contributes greater formation of void than in controlled environment.

\section{ACKNOWLEDGEMENT}

The International Islamic University Malaysia funded this project through the Research Endowment Grant B (EDWB 0906-333) and the Ministry of Higher Education Malaysia funded this project through Fundamental Research Grant Scheme (FRGS 0510-127). The authors gratefully acknowledge the financial support.

\section{REFERENCES}

[1] R.J. Ehlers, P.J. Ennis, L. Singheiser, W.J. Quadakkers, and T. Link. "Significance of scale spalling for the lifetime of ferritic 9-10\% $\mathrm{Cr}$ steels during oxidation in water vapour at temperatures between 550 and $650{ }^{\circ} \mathrm{C}$." Proceedings of the European Federation of Corrosion Workshop. 2001.

[2] A. Rahmel, and J. Tobolski. "Einfluss von Wasserdampf und Kohlendioxid auf die Oxidation von Eisen in sauerstoff bei hohen Temperaturen." Corrosion Science 5.5 (1965): 333-340.

[3] A. Rahmel, and J. Tobolski. "Einfluß von Wasserdampf und Kohlendioxyd auf die Oxydation von Eisen-Silicium-Legierungen in Sauerstoff bei Temperaturen von 750 bis $1050^{\circ} \mathrm{C} . "$ Werkstoffe und Korrosion 16.8 (1965): 662-676

[4] J. Ehlers, D.J. Young, E.J. Smaardijk , A.K. Tyagi , H.J. Penkalla , L. Singheiser , W.J. Quadakkers. "Enhanced oxidation of the 9\% Cr steel P91 in water vapour containing environments." Corrosion Science 48 (2006): 3428-3454

[5] J. Żurek, E. Wessel, L. Niewolak, F. Schmitz, T. -U. Kern, L. Singheiser, and W. J. Quadakkers. "Anomalous temperature dependence of oxidation kinetics during steam oxidation of ferritic steels in the temperature range 550-650 ${ }^{\circ} \mathrm{C}$." Corrosion Science 46.9 (2004): 2301-2317 
IIUM Engineering Journal, Vol. 12, No. 5, 2011: Special Issue -1 on Science and Ethics in Engineering Kaderi et al.

[6] L. Mikkelsen, and S. Linderoth. "High temperature oxidation of $\mathrm{Fe}-\mathrm{Cr}$ alloy in $\mathrm{O}_{2}-\mathrm{H}_{2}-\mathrm{H}_{2} \mathrm{O}$ atmospheres; microstructure and kinetics." Materials Science \& Engineering A, 361 (2003): 198-212

[7] T. Maruyama, N. Fukagai, M. Ueda, and K. Kawamura. "Chemical Potential Distribution and Void Formation in Magnetite Scale Formed in Oxidation of Iron at 823 K." Materials Science Forum 461-464 (2004): 807-814

[8] M. Ueda, K. Kawamura and T. Maruyama. "Void formation in Magnetite Scale Formed on Iron at $823 \mathrm{~K}$-Elucidation by Chemical Potential Distribution-." Materials Science Forum 522-523 (2006) 37-44

[9] T. Maruyama, and M. Ueda. "Void Formation Induced by the Divergence of the Diffusive Ionic Fluxes in Metal Oxides Under Chemical Potential Gradients." Journal of the Korean Ceramic Society 47.1 (2010): 8-18

[10] W. D. Kingery, H. K. Bowen, and D. R. Uhlmann. Introduction to Ceramics, Second Edition, pp. 526-530, Wiley - Interscience Publication, New York, USA 1976

[11] K. Akiba, M. Ueda, K. Kawamura, and T. Maruyama. "Quantitative Prediction of Voids Formation in a Growing Nickel Oxide Scale at 1373 K." Materials Transactions 48.10 (2007): 2753-2761 